\title{
First record of Blankaartia sinnamaryi (Floch \& Fauran, 1956) (Trombidiformes: Trombiculidae) parasitizing the striped owl in Northeastern Brazil
}

\author{
Primeiro registro de Blankaartia sinnamaryi (Floch \& Fauran, 1956) \\ (Trombidiformes: Trombiculidae) parasitando uma coruja-listrada no Nordeste \\ do Brasil
}

\author{
Ricardo Bassini-Silva1,2* (1); Fernando de Castro Jacinavicius² (1); Matheus Huang-Bastos 1,2 (D); \\ Aksa Ingrid Vieira Batista ${ }^{3}$ (1); Nathália Caroline Souza da Silva ${ }^{4}$ (D); Thiago Ferreira Lopes Nery ${ }^{4}$ (D); \\ Josivania Soares Pereira ${ }^{3}$ (D); Cal Welbourn ${ }^{5}$ (D); Ron Ochoa ${ }^{6}$ (D); Darci Moraes Barros-Battesti2,7 (D)

\begin{abstract}
${ }^{1}$ Departamento de Medicina Veterinária Preventiva e Saúde Animal, Faculdade de Medicina Veterinária e Zootecnia - FMVZ, Universidade de São Paulo - USP, São Paulo, SP, Brasil

${ }^{2}$ Laboratório de Coleções Zoológicas, Instituto Butantan, São Paulo, SP, Brasil Rural do Semi-Árido - UFERSA, Mossoró, RN, Brasil

${ }_{4}^{4}$ Parque Zoobotânico Arruda Câmara, João Pessoa, PB, Brasil

${ }^{5}$ Smithsonian Institution, National Museum of Natural History, National Insect and Mite Collection, Washington, D.C., USA

${ }^{6}$ Systematic Entomology Laboratory, United States Department of Agriculture, Agricultural Research Service, Beltsville, MD, USA

${ }^{7}$ Departamento de Patologia, Reprodução e Saúde Única, Faculdade de Ciências Agrárias e Veterinárias, Universidade Estadual Paulista - UNESP, Jaboticabal, SP, Brasil
\end{abstract} \\ ${ }^{3}$ Laboratório de Parasitologia Animal, Departamento de Biociências, Centro de Ciências Biológicas e da Saúde, Universidade Federal
}

\begin{abstract}
How to cite: Bassini-Silva R, Jacinavicius FC, Huang-Bastos M, Batista AIV, Silva NCS, Nery TFL, et al. First record of Blankaartia sinnamaryi (Floch \& Fauran, 1956) (Trombidiformes: Trombiculidae) parasitizing the striped owl in Northeastern Brazil. Braz J Vet Parasitol 2021; 30(3): e003121. https://doi.org/10.1590/S1984-29612021042
\end{abstract}

\begin{abstract}
The chigger species Blankaartia sinnamaryi (Floch \& Fauran) has been collected mainly from birds with a few records from reptiles and mammals. In Brazil, this species has been found on birds in the Minas Gerais and Rio de Janeiro states. Here, we report the first record of $B$. sinnamaryi parasitizing the striped owl, Pseudoscops clamator (Vieillot), in the Paraíba state, Brazil (northeastern region).
\end{abstract}

Keywords: Chigger mites, ectoparasites, birds, Paraíba state, trombiculiasis.

\section{Resumo}

A espécie de trombiculídeo, Blankaartia sinnamaryi (Floch \& Fauran) tem sido coletada principalmente parasitando aves, com alguns registros em répteis e mamíferos. No Brasil, essa espécie foi encontrada em aves nos estados de Minas Gerais e Rio de Janeiro. No presente estudo, relatamos o primeiro registro de $B$. sinnamaryi parasitando a coruja-listrada, Pseudoscops clamator (Vieillot), no estado da Paraíba, Brasil (região Nordeste).

Palavras-chave: Trombiculídeos, ectoparasitas, aves, Paraíba, trombiculíase.

The Neotropical and Nearctic chigger species Blankaartia sinnamaryi (Floch and Fauran, 1956) has historically been found parasitizing birds but also rarely parasitizing reptiles and mammals (Bassini-Silva et al., 2017, 2018). Little is known about this widespread species that has been found in the following countries: Costa Rica (Arnold, 1970; Stekol'nikov et al., 2007), Cuba (Daniel \& Stekol'nikov, 2003), French Guiana (Floch \& Fauran, 1956), Jamaica (Brennan,

Received March 2, 2021. Accepted March 26, 2021.

Funding: This work was supported by the Conselho Nacional de Desenvolvimento Científico e Tecnológico under the Grant CNPq no. 377343/2015-3, 377342/2015-7, 440639/2015-8, 454907/2014-1, 377976/2014-8 (DMB-B) and CNPq no. 377976/2014-8 (FCJ); by the Fundação de Amparo à Pesquisa do Estado de São Paulo under the Grant FAPESP no. 2010/51875-9 (DMB-B), 2019/19853-0 (FCJ), 2017/01416-7 and 2018/24667-8 (RB-S). This study was financed in part by the Coordenação de Aperfeiçoamento de Pessoal de Nível Superior - Brasil (CAPES) - Finance Code 001.

*Corresponding author: Ricardo Bassini-Silva. E-mail: ricardo.bassini@gmail.com.

This is an Open Access article distributed under the terms of the Creative Commons Attribution License, which permits unrestricted use, distribution, and reproduction in any medium, provided the original work is properly cited. 

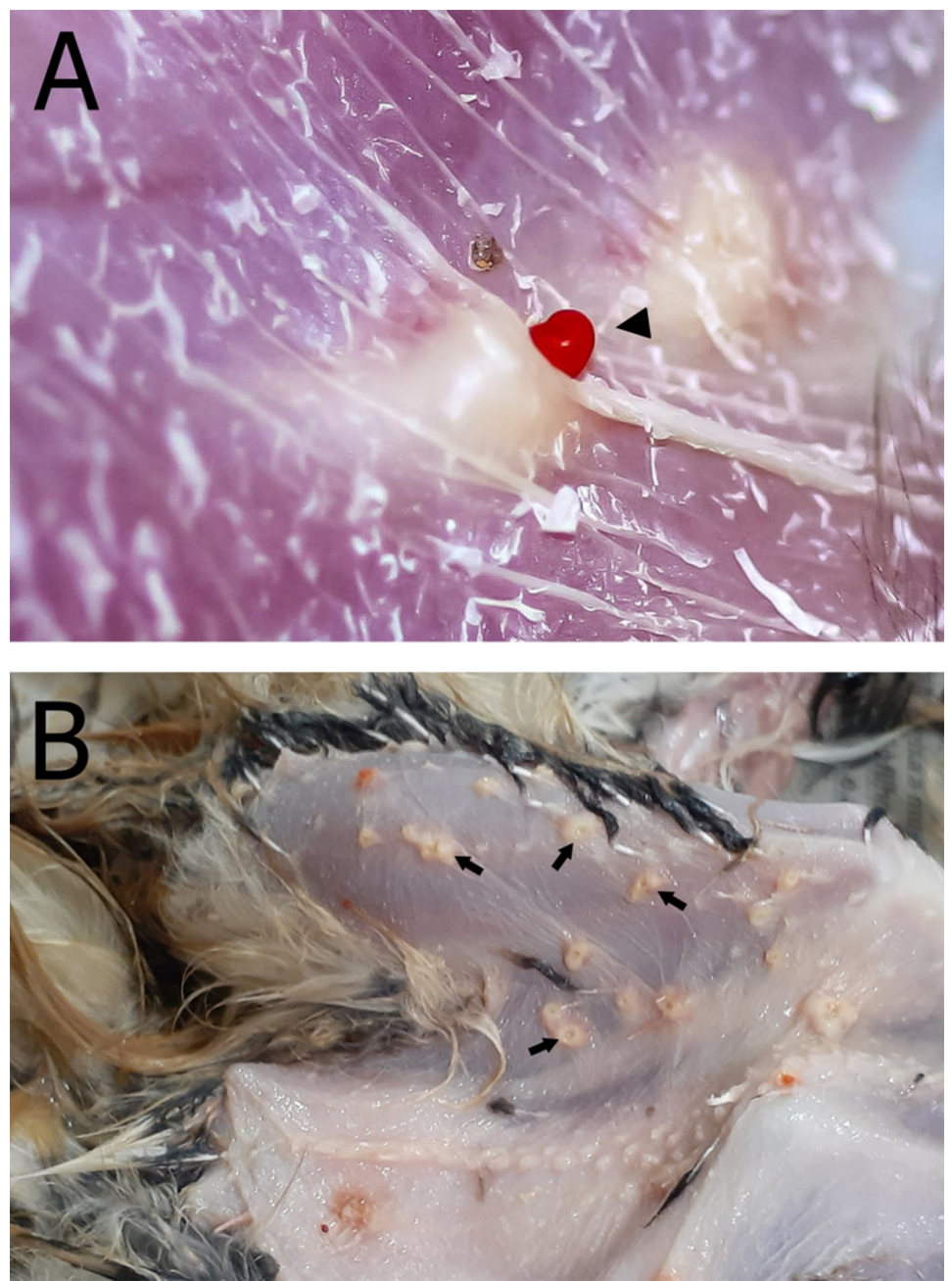

Figure 1. Larvae of Blankaartia sinnamaryi attached to their host. (A) Close up of a larva parasitizing the host; (B) Saccular lesions on the owl's flank and hind limb. The Black arrows are pointing out the injuries.

1953), Panama (Brennan \& Yunker, 1966), Peru (Brennan \& Jones, 1961), Suriname (Brennan \& van Bronswijk, 1975), Trinidad \& Tobago (Brennan \& Jones, 1960), USA (Brennan, 1965; Spalding et al., 1997), and Venezuela (Brennan \& Reed, 1975). Bassini-Silva et al. $(2017,2018)$ recently discovered this species in Minas Gerais and Rio de Janeiro states (southeastern Brazil), parasitizing bird species in the Passeriformes and Piciformes orders. Here, we are reporting this species parasitizing the striped owl, Pseudoscops clamator (Vieillot, 1808) (Strigiformes: Strigidae) in Paraíba State, in the northeastern Brazil, for the first time. Also, we are providing notes on the trombiculiasis caused by this mite in its host.

A wild young male $P$. clamator was rescued alive in João Pessoa Municipality, Paraíba State $\left(34^{\circ} 50^{\prime} 0^{\prime \prime} \mathrm{W}, 7^{\circ} 5^{\prime} 0^{\prime \prime} \mathrm{S}\right)$ by the State Environmental Police. The owl was sent to the Zoobotanic Park Arruda Câmara, João Pessoa municipality, Paraíba state for care due to a trauma wing and hind limb injury due to an electric shock. During the animal's examination, saccular lesions with "red dots" inside were observed (Figure 1A) along the animal's flank and hind leg. Several more saccular lesions also on the flank were observed without red dots (Figure 1B). These lesions were accompanied by a small accumulation of what appeared to be connective tissue. The owl did not show any itching or any other clinical signs of ectoparasites.

Soon after, the owl was euthanized and it was realized that the red dots were chiggers which were removed with the aid of tweezers and scalpel. Two larvae were recovered by veterinarians who stored them in $70 \%$ alcohol. The recovered larvae were sent to the Laboratório de Coleções Zoológicas (LCZ), Instituto Butantan, São Paulo State for identification. The material was slide-mounted in Hoyer's medium according to Walter \& Krantz (2009) and deposited in the Acari Collection of Butantan Institute (IBSP), under the accession number IBSP 16505.

The two larvae slide-mounted were identified as Blankaartia sinnamaryi using the published genera chigger key by Brennan \& Goff (1977). And, the species was confirmed by comparison with the material identified by 
Bassini-Silva et al. $(2017,2018)$ deposited in the IBSP collection. The following characteristics identify this species: heart-shaped idiosoma; palptibia with nude dorsal and lateral setae plus a branched ventral seta; adoral setae branched; trifurcate odontus (Odo); pentagonal prodorsal sclerite; C row with 8 setae; D row with 6 setae; Ta I with $\varepsilon$ positioned distal to $\omega$, and only one mastiseta on Ta III (Bassini-Silva et al., 2017, 2018).

This case report represents the third time $B$. sinnamaryi was collected parasitizing birds in the Order Strigiformes. Brennan \& Yunker (1966) reported this species parasitizing the Middle American screech owl, Megascops guatemalae (Sharpe 1875), and the mottled owl, Strix virgata (Cassin 1849). Pseudoscops clamator is designated a new host for B. sinnamaryi.

The lesions observed in this case were identical to those described by Bassini-Silva et al. (2018). These lesions are easy to detect because chigger larvae usually are red and deform the bite region. However, these chiggers are difficult to collect because in many cases the chiggers have already detached leaving only the host lesion.

In the present study, we highlight the species' importance as a cause of trombiculiasis in its hosts. This case report is the first time that the species $B$. sinnamaryi is collected in northeastern Brazil. It also represents the first report of a chigger from Paraíba state.

\section{Acknowledgements}

To Gabrielle Ribeiro de Andrade and Maria Cristina Ferreira do Rosário for technical contribution, Debra Creel, Andrew Ulsamer (SEL-USDA), and Armando Rosario-Lebron (APHIS-USDA) for their help with references and technical support. To the Smithsonian Natural History Museum and National Agricultural Library (NAL-USDA), SEL-USDA for support and assistance with specimens and references. Mention of trade names or commercial products in this publication is solely for the purpose of providing specific information and does not imply recommendation or endorsement by the USDA; USDA is an equal opportunity provider and employer.

\section{References}

Arnold KA. Notes on Avian Ectoparasites from Costa Rica. I. Acarina and Diptera. Rev Biol Trop 1970; 16(2): $259-265$.

Bassini-Silva R, Jacinavicius FC, Maturano R, Muñoz-Leal S, Ochoa R, Bauchan G, et al. Blankaartia sinnamaryi (Trombidiformes: Trombiculidae) parasitizing birds in southeastern Brazil, with notes on Rickettsia detection. Brazil. Rev Bras Parasitol Vet 2018; 27(3): 354-362. http://dx.doi.org/10.1590/s1984-296120180057. PMid:30184002.

Bassini-Silva R, Jacinavicius FC, Mendoza-Roldan JA, Daemon E, Barros-Battesti DM. Description of Blankaartia shatrovi n. sp. (Acari: Trombiculidae) from Brazil. J Med Entomol 2017; 54(1): 82-90. http://dx.doi.org/10.1093/jme/tjw149. PMid:28082634.

Brennan JM, Goff ML. Keys to the genera of chiggers of the western hemisphere (Acarina: trombiculidae). J Parasito/ 1977; 63(3): 554-566. http://dx.doi.org/10.2307/3280021. PMid:68115.

Brennan JM, Jones EK. Chiggers of Peru (Acarina: trombiculidae). Acarologia 1961; 3(2): 172-205.

Brennan JM, Jones EK. Chiggers of Trinidad, B.W.I. (Acarina: trombiculidae). Acarologia 1960; 2(4): 493-540.

Brennan JM, Reed JT. A list of Venezuela chiggers, particularly of small mammalian hosts (Acarina: trombiculidae). Brigh Young Univ Sci Bull 1975; 20(1): 45-75.

Brennan JM, van Bronswijk JEMH. Parasitic mites of Surinam XXI. New records of Surinam and certain French Guiana chiggers with the description of a new species of Loomisia Brennan \& Reed, 1972 (Acarina: trombiculidae). J Med Entomol 1975; 12(2): 243-249. http://dx.doi.org/10.1093/jmedent/12.2.243. PMid:1159750.

Brennan JM, Yunker CE. The chiggers of Panama (Acarina: Trombiculidae). In: Wenzel RL, Tipton VJ, editors. Ectoparasites of Panama. Chicago: Field Museum of Natural History; 1966. p. 221-266.

Brennan JM. A note on the chiggers of Jamaica (Acarina: trombiculidae). J Parasitol 1953; 39(3): 292-295. http://dx.doi. org/10.2307/3273952. PMid:13053313.

Brennan JM. Five new chiggers from Southwestern United States (Acarina: trombiculidae). J Parasito/ 1965; 51(1): 108-113. http:// dx.doi.org/10.2307/3275656. PMid:14259470.

Daniel M, Stekol'nikov AA. Chigger mites (Acari: Trombiculidae) new to the fauna of Cuba, with the description of two new species. Folia Parasitol (Praha) 2003; 50(2): 143-150. http://dx.doi.org/10.14411/fp.2003.025. PMid:14560976.

Floch H, Fauran P. Sur deux espèces du genre "Trombicula” (Acariens, Trombiculidés) nouvelles pour la faune de la Guyane Française: "Trombicula alfreddugesi" (Oudemans, 1910) et "Trombicula sinnamaryi" n. sp. Archs Inst Past Guy Ter 1956; 17(405): 1-7. 
Spalding MG, Wrenn WJ, Schwikert ST, Schmidt JA. Dermatitis in young Florida sandhill cranes (Grus canadensis pratensis) due to infestation by the chigger, Blankaartia sinnamaryi. J Parasitol 1997; 83(4): 768-771. http://dx.doi.org/10.2307/3284263. PMid:9267428.

Stekol'nikov AA, Literák I, Capek M, Havlćk M. Chigger mites (Acari: Trombiculidae) from wild birds in Costa Rica, with a description of three new species. Folia Parasitol (Praha) 2007; 54(1): 59-67. http://dx.doi.org/10.14411/fp.2007.008. PMid:17441438.

Walter DE, Krantz GW. Collecting, rearing, and preparing specimens. In: Krantz GW, Walter DE, editors. A manual of acarology. 3rd ed. Lubbock: Texas Tech University Press; 2009. p. 83-96. 